Volume 3, Issue 1, February 2018, Pages: 237, DOI: http://dx.doi.org/10.19082/ah237

\title{
DER P 5 FROM HOUSE DUST MITES HDM: EFFECT OF MUTATIONS AND HIGH TEMPERATURE ON THE FOLDING AND STABILITY OF THIS ALLERGEN, A POTENTIAL DIAGNOSTIC MARKER ALLERGEN FOR HOUSE DUST MITE ALLERGY
}

\author{
Sadjia Lahiani ${ }^{1,2}$ and Moreno Galleni ${ }^{2}$
}

1: Ph.Ds in Molecular Biology and Biotechnology, Assistant, Department of Biology, Faculty of Sciences, University of Boumerdes, Algeria.

Email: sadjialhiani@yahoo.fr

2: PhD, Prof. Centre for Protein Engineering, i-Life. Dept of Life Sciences. University of Liege. Institut de Chimie B6a. Quartier Agora. Allée du 6 Août, 11. Sart Tilman - B4000 Liege, Belgium.

Email: mgalleni@Ulg.ac.be

\section{TYPE OF ARTICLE: CONFERENCE ABSTRACT}

\begin{abstract}
Background: Allergic diseases constitute a health problem worldwide, allergy to house dust mites is the most common cause of asthma and allergic rhinitis. Der p 5 was reported as an important allergen in Dermatophagoides pteronyssinus, which is particularly recognized in patients suffering from asthma.

Methods: By recombinant DNA technology, folded and infolded Der $\mathrm{p} 5$ allergens were produced for diagnostic, and therapeutic properties. In this study, Der $\mathrm{p} 5$-encoding cDNA was cloned and expressed in Pichia pastoris. In parallel, mutated forms were generated by site directed mutagenesis to study the stability of this allergen. rDer p 5 and mutants were purified to homogeneity and characterized by mass spectroscopy and circular dichroism. IgE reactivity was tested with sera from 64 mite-allergic patients, and the physical properties of these different forms have been compared.

Results: rDer p 5 and all mutated forms are heat-stable proteins with predominantly $\alpha$-helical secondary structure which reacted with IgE from $35 \%$ of mite-allergic patients' sera, and all mutated forms show a high capacity binding of IgEs. The described rDer p 5 and its stability explain its antigenic capacity.

Conclusion: These molecules may be useful for diagnosis and immunotherapy of house dust miteallergic patients.

KEYWORDS: House dust mites, Recombinant allergens, Immunodiagnosis.
\end{abstract}

\footnotetext{
Abstracts of Second International Conference on Health Sciences and Medical Technologies, 10-12 October 2017, Tlemcen, Algeria (ICHSMT-17)

(C) 2018 The Authors. This is an open access article under the terms of the Creative Commons Attribution-NonCommercialNoDerivs License, which permits use and distribution in any medium, provided the original work is properly cited, the use is non-commercial and no modifications or adaptations are made.
} 